\title{
An Analysis on the Legal Liability of Shared Car
}

\author{
Zebo Liu \\ School of Literature, Law and Economics \\ Wuhan University of Science and Technology \\ Wuhan, China
}

\begin{abstract}
Since the establishment of OFO shared bicycle in 2014, the shared travel business has started to develop rapidly in China. From the single shared bicycle to the shared cars, a variety of shared travel modes have been gradually developed. The emergence of shared cars aims at repeatedly the successful service of the shared cycling. It can optimize social transportation resources, bring convenience to people's lives and solve parts of the public demands of the community. However, the rise of emerging industries inevitably leads to numerous legal issues such as the responsibility attribution of infringement of shared vehicles in many cases, the responsibility attribution of breaking rules of shared vehicle, the malicious shared vehicles, and illegal compulsory fines of the emerging shared car companies and so on. In this paper, the author would make research on how to carry out legal regulation of the problems of shared cars.
\end{abstract}

Keywords—car-sharing; legal responsibility; behaviors

\section{INTRODUCTION}

With the rapid development of the Internet economy in the environment of big data of social Internet, the shared economy is also emerging in this context. The success of OFO, Mobike and other shared bicycle modes, and the support of government and various social sectors have also made an emerging industry of shared travel. People aren't satisfied with single shared travel mode of shared bikes. And they intend to copy the successful shared mode. And then, the shared cars also gradually appear in people's daily life. In the existing mode of shared car, the users can enjoy the car with only a few yuan for an hour by uploading the driver's license and delivering a deposit of several hundreds or thousands yuan. However, the threshold of shared car is too low. As the complex motor vehicle, it will inevitably have more legal issues to be solved in the process of sharing.

\section{THE GENERATION AND AdVANTAGES OF SHARED CAR}

\section{A. The Generation of Shared Car}

Shared cars firstly appeared in the 1940s, and it was invented by the Swiss. They organized "self-driving cooperatives" across the country. When a person ran out of cars, they would give the keys to the next person. In the later, Japan, Britain and other countries followed this concept. However, they didn't form the scale. With the development of networks, electronic keys and satellite positioning systems, shared car not only has technical support, but also integrates with technologies such as mobile phone positioning and APP to determine the basis for sharing the car.

\section{B. The Advantages of Shared Car}

In the current society, the serious pollution of the environment, the shortage of petroleum resources, the shortage of transportation resources and other issues are always plaguing the society. The emergence of shared cars can greatly reduce the air pollution, reduce the dependence on energy and help ease traffic blockage and road abrasion. And many people share one car, but also help optimize the utilization of social resources. And then, it would save the waste resources.

\section{THE LEGAL ISSUES OF SHARED CAR}

Shared cars are simple and convenient for people's life. At the same time, it also brings a series of problems to the society. Among these issues, the traffic safety accident of shared car is an outstanding example. In Tangshan, Hebei province, a woman who did not obtain a driver's license, $\mathrm{Li}$ was drunk. And her friend, drunk Huang could register an account and scan the code. Then, $\mathrm{Li}$ used a shared car. $\mathrm{Li}$ started and drove the shared car, crashed a parked vehicle on the roadside and hit a sanitation worker. Ultimately, it had led to the death of sanitation worker with an invalid rescue. Subsequently, the police took blood tests of the driver Li. After testing, Li's blood alcoholicity was $152 \mathrm{mg} / 100 \mathrm{ml}$. It was drunk driving. And the traffic police checked identity information of $\mathrm{Li}$. He found that $\mathrm{Li}$ didn't obtain motor vehicle driving license according to law. And Li drove the car without a license. A drunk driver without license could simply start a motorized vehicle by borrowing the driver's license of another drunk friend. It caused such serious consequences. This case deeply exposed the problems of shared car in the real life. There are possible problems and the division of responsibility between the users of shared cars and the companies provide the service of shared car.

Shared cars not just are ordinary materials in people's daily life, but also are special movable property-motor vehicles. People drive the shared cars on the public transport. And it would directly endanger the life and health of the people and cause more damage than ordinary ones. And then, the law also has its own specific strict rules. There are many issues such as the driving qualifications, motor vehicle conditions, driving conditions and accidental attribution and so on. However, with the development of the shared car 
model, the above problems would inevitably lead to more complicated cross-cutting situations. What are the obligations of the shared car companies? And what are the obligations of the users in the shared car service? For example, an unmanned driver without driving qualification borrows a driver's license and uses the shared car with the problems. How to distinguish the responsibilities among these accidents? Once, it appears this complex situation. The existing laws can't accurately explain the situation. It is helpful to protect the legal rights and interests of both parties and safeguard the healthy development of this emerging industry by studying and allocating the responsibility of shared car companies and users in the process of sharing car services in the new situation.

\section{The LeGal NATURE OF SHARED CARS}

\section{A. The Relationship with Shared Economy}

For shared cars, some think that the underlying rationale of their business model is shared economy. The shared economy was firstly proposed in "Community Structure and Collaborative Consumption: A Routine Activity Approach" in 1978 by Marcus Felson, a professor of sociology at Texas State University in the United States, and Joe L. Spaeth, a professor of sociology at the University of Illinois. 1

\section{B. Shared Car Is a New Rental Relationship}

In fact, shared cars differ from normal models of Uber. Essentially, it is a new type of time-sharing leasehold relation. Uber has millions of cars registered on the platform, but none of them is owned by Uber. The shared car adopts the model of car manufacturer-leasing or rental business model. And the users must pay certain fees before using. Therefore, it can be seen that the shared cars put on the market are basically manufactured, purchased and dominated by the company. And the users, as the lessee, deliver the rent to the sharing car company. Therefore, it is actually a timesharing leasing mode. In addition, before registering the account of shared car, the user should read the agreement. And the agreement also indicates that there is a lease relationship between the shared car company and the user. Different from ordinary leasing, this new type of leasing is that the leased property-shared car is actually separated from the actual supervision of the lessor in a time-sharing manner over a long period. And the leasing process is implemented by the mobile network. The lessee's qualification review obligations are reduced to the minimum of procedural review, which will have an adverse impact on the division of responsibilities in the future.

\section{THE RESPONSIBILITY OF THE OPERATING COMPANY OF SHARED CAR}

"Tort Liability Law" clearly stipulates: "In the conditions of leasing, borrowing and other circumstances, the owner and the user are not the same person in the event of a traffic

Marcus Felson, Joe L.Spaeth (1978), “Community Structure and Collaborative Con-sumption: A routine activity approach.” American Behavioral Scientist, 21(March-April), 614-24 accident. If the responsibility belongs to the motor vehicle, the insurance company should make compensation in the scope of motor vehicle compulsory insurance. In the deficient part, the motor vehicle user shall assume the liability for compensation. If the owner of the motor vehicle has made any mistake in the occurrence of the damage, he should bear the corresponding liability and make compensation." According to Article 49 of the Tort Liability Law, the owner's fault refers to the failure of the lessor or the lender in examining the driving qualification of the lessee or borrower, and the failure of concealing the problems of the motor vehicle.

\section{A. The Qualification Review Obligations of the Company of Shared Car}

According to the above laws and regulations, it can be concluded that the shared car company, as the lessor should fulfill its obligations of qualification examination. In the real ordinary car rental company, the lessor will effectively review the driving qualification of the lessee and the current physical condition. And it can effectively refuse to provide rental business for the people who provide false qualifications. And then, it can clearly divide the responsibility attribution. However, in the process of renting a shared car by using the network of mobile phone, the shared car company, as the lender generally provides the car rental service for the lessee based on a simple and limited examination method such as uploading the driver's license by photographing, which obviously reduces the qualification review obligations of the leaser in the legal provisions.

In real life, there are many cases of drunk driving of motor vehicles and driving without a driving license. And serious traffic accidents caused by illegal driving of motor vehicles would lead to car crashing and the death. If the actual lessee fraudulently use another person's driving license to make registration, or pick up someone else's mobile phones registered, they are able to use the rental services of shared car. If it is unable to identify the actual lessee, or the actual lessee in reality has no conditions to bear the liability, shared car companies only evade liability by the minimum of virtual qualification review. And then, it would inevitably cause the unfairness. In the opinion of the author, if the lessee would have the service of shared cars by uploading solely the driver's license and the leasers haven't taken proper qualification review obligations. In short, the users use shared cars, and the operating company of shared car can't make effective qualification review of automobile operators. In the case of an accident, it would result in personal or property damage, and the liability for damages would be attributed to the fault of the user. This will aggravate the user's responsibility, and it may not be conducive to the implementation of the victim's relief during the execution of the court. ${ }^{2}$

\footnotetext{
Fu Rui. Research on legal problems of shared travel. Law and Society. 2017.5
} 


\section{B. Regulation and Inspection Obligations of Shared Car Company}

First of all, shared car company, as the leaser, provides car rental service. And the leaser should do its duty to provide trouble-free motor vehicles. For the car-sharing industry, the lessee could park and start at anywhere immediately, and the next lessee can continue to use the car "seamlessly". In the case, this shared car company can't check the status of the car for a long time. And the shared car would be damaged by a third person; or some of the key components are being disassembled; or the components related with traffic safety such as tires are damaged. The lessee does not have the knowledge of the car. And they can't make a professional vehicle inspection before driving on the road. Then, it would lead to the damage of personal and property caused by the traffic accidents. The responsibility of shared car companies can be exempted relying on the disclaimer of the agreement. And it would aggravate the lessee's liability. Shared car, as a motor vehicle, would inevitably cause vehicle damage during driving and parking. If there is no check after driving, the responsibility attribution of the damage is also a major issue.

Based on this, shared car company should bear the responsibility to check the shared car after using this car. And the shared car company could make the video inspection and other means of testing. If the shared car company doesn't carry out the test, and they can't blame the accident liability caused by car damage to the car user. Also, the shared car company can't blame the responsibility of car damage to the previous lessee. It would undertake the wrong liability of damage.

\section{The Deduction Service of Shared Car Company Is Illegal}

According to relevant media reports, many "shared car" companies have a rule that the company has the right to deduct violation fine and agency fees in the account of illegal users. The author believes that such companies currently have no legal rights to deduct the scores and fines. And the shared car company, as a commercial entity, does not have the legal right to do this thing. As the leasers, shared car companies can urge the lessee to carry out the punishment as soon as possible. If the lessee can't fulfill the responsibility within the prescribed time, the shared car company can deduct the guarantee fines from the amount of the lessee. And if the shared car company directly deducts the fines and agency fees, it would clearly violate the legitimate rights and interests of users. We hope that it should clearly regulate such phenomena at all localities. At the same time, we should put an end to such violations of shared car companies.

\section{THE RESPONSIBILITY OF SHARED CAR USERS}

\section{A. The Main Responsibility of the Driver of Shared Car}

In "shared car service agreement," Article 3 of "user registration and certification" user qualification states: "If the

\section{Society. 2017.5}

user does not get $\mathrm{C} 2$ motor vehicle driving license, or driving license has been revoked, and the users who have various diseases such as epilepsy, heart disease, high blood pressure, temporary dizziness, visual impairment, hearing impairment, disability may not drive a motor vehicle in laws and regulations. This article explains the subject qualification of using shared cars. The users should have the qualifications, and the users also should provide legal and valid qualification certificate to the shared car company.

If the users of the shared car violate the agreement of the shared car, or illegally authorize the actual users who doesn't have qualification to use the shared car, the users not only bear the damage caused by the shared car, but also should compensate for the loss of the shared car.

\section{B. The Obligations of Pre-driving Inspection}

As a motor vehicle, shared car is different from shared bicycle in general. In the case of an accident, it can lead to more serious damage. Shared Car Company lacks the necessary real-time monitoring of the shared car after the use. When applying for the use of shared car, the user should perform a simple and necessary check on the appearance and the basic situation of the car (such as obvious tire pressure loss, brake pedal integrity, etc.). If the user knowingly drives motor vehicle with too much confidence and problems, it may cause personal or property damage and the user can't blame all liability to the shared car. And the user should be responsible for the damage within the scope of liability.

\section{The Responsibility of Violation and Infringement of the Shared Car}

Shared car users actually have special rental car sharing services in the process of driving a shared car. And the agreement signed by the user and the shared car company is a lease contract. Then, as renters, shared car users should be responsible for personal and property damage caused by this accident in the process of driving the shared car.

In addition, as motor vehicles, shared car users may also be subject to administrative penalties if they violate the "Regulations on Road Traffic Safety" and corresponding regulations as they run red lights, retrograde, violate line limits, and park at will. In the shared car mode, as actual users, shared car users should bear the penalty of the deduction of fines and points in the driving process with the violation of rules and regulations.

\section{Malicious and Inundant Liability for Compensation}

"Contract Law" states: the leaser should keep the leased things properly. Due to improper care of the leaseholds, it may cause damage and loss. And it should bear the liability for damages. In the shared car service, the normal driving behaviors would also cause wear and tear. And the users have no fault and should not be liable for compensation. However, there are also malicious users driving shared car to make "drift" or "leap", and other high-risk driving behaviors. And these malicious damages to the vehicle are far beyond the normal wear and tear of the vehicle in the normal driving. In this case, the damage to the shared car should be attributed 
to the malicious behaviors of the users. And the user should bear the corresponding liability.

\section{CONCLUSION}

As parts of the Internet economy with innovation and pluralism, shared cars are gradually entering the daily life of people with the rapid development of Internet. According to the speech of Wu Chungeng, the spokesman of the Ministry of Transport, the Ministry of Transport of the PRC encourages and supports this innovative way of "Internet + traffic trip". However, with the emergence of new industries, there are a series of new legal issues. When the problems occur, effective legal regulation should be made to solve these problems arising in the new industries. And it should clear the legal relations and the legal responsibilities among them. With the cooperation among governments, enterprises and the society, it could better promote the soundness and healthy development of the system.

\section{REFERENCES}

[1] Tang Qingli. The regulation of "special car" shared economics [J]. China Law. 2015(4).

[2] Xiao Yue. The thorns development of shared bike [J]. Legal Person. 2016 (11).

[3] Weitzman. "Shared Economy" [M]. Beijing: China Economic Publishing House. 1986.

[4] Zhou Hongchun. Study on Economic Strategy of Shandong province. 2016 (6).

[5] Chen Yaodong, Ren Rongqing. Reflections on the legal nature of leasehold-type timeshare [J]. Journal of Huaqiao University, 2005 (4).

[6] Wang Deming. Research on legal issues of the regulatory of car rental company [D]. Harbin Institute of Technology. 2014 (10).

[7] Lin Xiaoyi. Analysis on the the legal regulation issues of the development of car rental industry [J]. Chinese Market. 2012 (1).

[8] Wei Zhulong. Analysis on the status quo and legal risk prevention of car rental industry [J]. Journal of Economic Research. 2011 (8).

[9] Han Liping. To promote the development of the legislation of car rental industry. Transport Manager World [J]. 2016 (3).

[10] Xu Tao. to identify the main responsibility of time-sharing lease in traffic accidents [J]. Legal system and society. 2017 (8). 